\title{
Barbara HARTLEB-KROPIDLO
}

Uniwersytet Wrocławski

\section{O PEWNYM ŚLUBNYM ZWYCZAJU W RELACJI MARKA TERENCJUSZA WARRONA}

\author{
ON A CERTAIN WEDDING CUSTOM IN VARRO'S ACCOUNT
}

This article focuses on a certain wedding custom presented by the ancient Roman scholar, Marcus Terentius Varro in his work De vita populi Romani. According to him Roman bride on her way to her new home used to carry three coins, and to dedicate them to her husband, to Household Lares and to Compital Lares.

Keywords: Varro, marriage, Roman religion, Lares, Roman coinage

Marek Terencjusz Warron (116-127 p.n.e.) uznawany za największego rzymskiego uczonego, zajmował się niemal wszystkimi dziedzinami nauki: gramatyką, retoryką, geometrią, astronomią, muzyką, medycyną i architekturą. Dzieła tego uczonego, których liczbę szacuje się na około 620 ksiąg, w wielkiej części zaginęły¹.

Jednym z nich było czteroksięgowe opracowanie $O \dot{z} y c i u$ narodu rzymskiego (De vita populi Romani) dedykowane Attykowi, które datuje się na lata czterdzieste I w. p.n.e. Treść dzieła obejmowała dzieje od czasów najdawniejszych, wypędzenie królów, konflikt zbrojny z Kartaginą aż do wojny między Cezarem i Pompejuszem. Być może było ono wzorowane na Bios Hellados Dikajarcha. Fragmenty De vita populi Romani zawdzięczamy głównie Noniuszowi, który przechował je w swojej encyklopedii De compendiosa doctrina ${ }^{2}$.

W pierwszej księdze De vita populi Romani, oprócz wielu opowieści z dziejów Rzymian epoki królewskiej, na przykład o zabójstwie Mettiusa Fufetiusa czy gwałcie dokonanym przez Tarkwiniusza Pysznego na Lukrecji, znajdujemy liczną

1 von Albrecht 1997: 593-616, zwł. 598; Kumaniecki 1977: 463-509: Myśliwiec 1990: 470-472.

${ }^{2}$ Autor encyklopedycznego dzieła łacińskiego przekazał prawie wszystkie ze 129 zachowanych fragmentów pisma Warrona. Na temat De vita populi Romani zob.: Cornell, Bispham 2013: 415-423. Wydania tekstu: Varro 1939: 280-316; Varro 2004. Wydanie De compendiosa doctrina Noniusza Marcellusa zob. Nonius 1903. 
grupę fragmentów, które stanowią opisy instytucji państwowych i religijnych, a także opisy dotyczące życia prywatnego, takie jak stroje, domy czy przedmioty codziennego użytku.

Jednym z nich jest lemmat przedstawiający pewien zwyczaj związany z zawarciem małżeństwa, który Noniusz Marcellus (852 L) uzupełnia uwagą, że te zagadnienia Warron opisał wyczerpująco (diligentissime percucurrit). Wiadomo zatem, że ten passus to zaledwie niewielki urywek opisu zwyczajów związanych z zawieraniem małżeństwa, który przedstawia tylko jeden element związany z ceremonią zaślubin, a mianowicie wejście panny młodej do domu męża.

Celem niniejszego artykułu jest przedstawienie, analiza oraz interpretacja wspomnianego testimonium, które przedstawia zwyczaj ślubny nieznany nam z innych źródeł literackich.

Non. De comp. doct. 852L:

Nubentes vetere lege Romana asses III ad maritum venientes solere pervehere atque unum, quem in manu tenerent, tamquam emendi causa marito dare, alium, quem in pede haberent, in foco Larium familiarum ponere, tertium, quem in sacciperione condidissent, conpito vicinali solere $\uparrow$ resenare.

Zgodnie ze starym prawem rzymskim panny młode przybywając do domu męża miały zwyczaj przynosić trzy asy. Jedną z monet, którą (kobiety) trzymały w ręku, tak, jakby chciały coś kupić, wręczały mężowi. Drugą, którą miały w bucie, umieszczały przy palenisku, przy którym czczono Lary rodzinne. Trzecią monetę, którą przynosiły w torebce, pozostawiały na ołtarzu poświęconym Larom Rozdroży33.

Warto w tym miejscu zwrócić uwagę na charakter rzymskiego małżeństwa oraz pewne praktyki związane z zaślubinami. Pamiętać należy przy tym, że w ciągu wielowiekowej historii Rzymu zachodziły w nich rozmaite zmiany, a pewne elementy pozostawały w niemal niezmienionej formie lub ewoluowały powoli, potwierdzając trwałość i dawność zwyczaju. Małżeństwo (łac. matrimonium, nuptiae) funkcjonowało w świadomości starożytnych Rzymian jako trwały związek mężczyzny i kobiety, zawarty poprzez wyrażenie przez nich chęci i zgody (consensus) na wspólne pożycie (Lind 2008: 31-43). Zawarcie go nie wymagało uczestnictwa jakiegokolwiek urzędnika państwowego ani spełnienia jakichkolwiek formalności. W definicji przekazanej przez Modestyna (Digesta Iustiniani 23, 2, $1^{4}$ ) czytamy:

Małżeństwo jest związkiem mężczyzny i kobiety, zespoleniem na całe życie, wspólnotą prawa boskiego i ludzkiego.

Nuptiae sunt coniunctio maris et feminae et consortium omnis vitae, divini et humani iuris communicatio.

${ }^{3}$ Przekład autorki. Zob. Flower 2017: 78-85.

${ }^{4}$ Hereniusz Modestyn, III w. n.e., znakomity prawnik rzymski, uczeń Ulpiana, autor wielu pism, $\mathrm{m}$ in. Differentiae (9 ks.), Responsa (19 ks.), Regulae (10 ks.). Jego pisma zostały zebrane w Corpus iuris civilis. Iustiniani digesta, zob. Mommsen 1872: 295; przekład za: Modestinus 2014: 201-211. 
Liczne i różne zwyczaje oraz rytuały stanowiły potwierdzenie wyrażenia zgody przez oboje małżonków. Można tu wskazać między innymi zaręczyny (sponsalia) i wprowadzenie żony do domu męża (deductio in domum mariti).

Zawarcie małżeństwa było wydarzeniem prywatnym, chociaż wywoływało konkretne skutki prawne, na przykład w zakresie pozycji społecznej i rodzinnej małżonków. Była to zatem instytucja obyczajowa, nie prawna. $\mathrm{Z}$ tego powodu nie istniała oficjalna, urzędowa forma zawarcia związku, a instytucje państwowe i religijne nie musiały w nim uczestniczyć, ani go potwierdzać. W wyniku zawarcia małżeństwa mężczyzna stawał się głową rodziny, pater familias, a kobieta zyskiwała pozycję mater familias. Definicje przytaczane przez rzymskich prawników, w większości z czasów cesarstwa, bazujące na wielowiekowej tradycji, precyzują i objaśniają powszechne rozumienie warunków oraz istoty małżeństwa, nie podają natomiast jego prawnej definicji ${ }^{5}$.

$\mathrm{O}$ ile zatem nie było formalno-prawnych przepisów regulujących zawieranie małżeństwa, to ślubny pochód $\mathrm{z}$ domu panny młodej do domu męża był widocznym znakiem jego zawarcia. Był także wyrazem zgody obojga narzeczonych na zmianę swojego statusu społecznego, który to termin (consensus) był przywoływany przez późniejszych jurystów jako niezbędny warunek zawarcia związku małżeńskiego ${ }^{6}$. Ta prywatna, lecz także widoczna, a więc publiczna uroczystość rodziła określone skutki prawne, takie jak przejście kobiety pod władzę męża oraz status potomstwa jako ślubnego.

Zawarcie małżeństwa było poprzedzone zaręczynami, podczas których narzeczeni w obecności rodziców (ich obecność była także wyrazem aprobaty tego wydarzenia) i świadków składali sobie obietnicę zaślubin ${ }^{7}$ Na potwierdzenie statusu narzeczonych kobieta otrzymywała od mężczyzny zaręczynowy pierścień, który nosiła na serdecznym palcu lewej ręki ${ }^{8}$.

${ }^{5}$ Wołodkiewicz, Zabłocka 1996: 92; Rozwadowski 1987: 237-247.

${ }^{6}$ Potwierdzenie warunku zgody obojga znajdujemy u wybitnego jurysty rzymskiego z II/III w. n.e. Domicjusza Ulpiana zachowane w Digestach Justyniana (Dig. Iust. 35, 1, 15), który wskazuje, że: Cui fuerit sub hac condicione legatum 'si in familia nupsisset', videtur impleta condicio statim atque ducta est uxor, quamvis nondum in cubiculum mariti venerit. nuptias enim non concubitus, sed consensus facit. Zob. Mommsen 1872: 499.

${ }^{7}$ Dla przesądnych Rzymian wyznaczenie daty ślubu wiązało się z licznymi ograniczeniami religijnymi, a mianowicie należało wybrać dzień, który określano jako fastus, czyli pomyślny. Dni pomyślne (dies fasti) oraz niepomyślne (dies nefasti) oznaczone były w kalendarzu układanym przez pontyfików i umieszczanym na forum. Oznaczone były w nim także święta stałe i ruchome, a także stałe dni miesiąca, czyli Kalendy, Nony i Idy. Nie wolno było wstępować w związki małżeńskie podczas świąt ku czci zmarłych, na przykład takich jak Parilia. Pewną informację na temat istnienia i znaczenia dni pomyślnych i niepomyślnych dla zawarcia małżeństwa przynosi nam Owidiusz w Kalendarzu poetyckim (Fast. 6, 219-234), gdy ojciec troszczący się o córkę mającą wyjść za mąż pragnie wybrać taki dzień uroczystości, aby przyniósł on pomyślność zarówno przyszłej żonie, jak i przyszłemu zięciowi, ponieważ to miało zapewnić szczęście rodzinie.

${ }^{8}$ O małżeństwie m.in. Marshall 1921: 175-179; Hersch 2010: 20-26; Benincasa 2013. 
Ze względu na konstrukcję społeczną i prawną rodziny rzymskiej w czasach republiki, w której najwyższą pozycję zajmował ojciec rodziny, pater familias, także relacje między małżonkami uwzględniały tę szczególną pozycję mężczyzny. Najczęściej zatem kobieta wychodząc za mąż przechodziła spod władzy ojca pod władzę męża. Wyróżniano dwa najczęstsze typy takich związków cum manu: confarreatio oraz coemptio ${ }^{9}$.

Confarreatio, którego nazwa pochodzi od placka orkiszowego, panis farreus, był ceremonią prawdopodobnie zastrzeżoną pierwotnie dla patrycjuszy. Wspomniany placek był podczas tej ceremonii składany przez nowożeńców Jowiszowi jako opiekunowi małżeństwa w obecności dziesięciu świadków, którym towarzyszyli dwaj kapłani: Pontifex Maximus oraz Flamen Dialis.

Coemptio, którego nazwa wywodzi się od czasownika emere, kupować, stanowi przekształcenie czynności mancipatio, czyli aktu przeniesienia własności przedmiotu. Podczas takiego aktu kupna, który wymagał obecności pięciu świadków oraz osoby, nazywanej libripens, trzymającej podczas tego aktu symboliczną wagę (początkowo, przed wprowadzeniem monet, odważano w ten sposób kruszec, zwłaszcza miedziany, jako zapłatę). Przekazanie własności $\mathrm{w}$ drodze mancypacji zyskało z czasem charakter symboliczny, realizowany przy użyciu jednego sesterca. Związek małżeński zawarty na zasadzie coemptio był więc symbolicznym zakupem żony bądź prawa do sprawowania nad nią władzy.

Przekaz Warrona, w którym mówi się o wręczeniu przez kobietę monety mężowi ,jakby coś kupowała" może budzić skojarzenia z coemptio. Podczas tej uroczystości władza nad nią ,zostaje kupiona” przez męża, czy natomiast przekazanie przez pannę młodą asa mężowi jest również symbolicznym aktem zakupu? Jeśli tak, co jest przedmiotem tej „transakcji”? Warron, który informuje nas o tym dawnym zwyczaju, nie zaspokaja w tej kwestii naszej ciekawości, ale w swoim przekazie udziela nam wskazówki: tamquam emendi causa, akcentując przede wszystkim podobieństwo gestu wykonanego przez kobietę do gestu podczas czynności zakupu ${ }^{10}$.

Sformułowanie vetus lex Romana użyte przez Warrona (rzeczownika lex autor z pewnością nie użył przypadkowo) oznacza dawne prawo, które stało się zwyczajem. Niejasna pozostaje kwestia, dlaczego Warron nie posłużył się tu terminem mos, być może chciał w ten sposób podkreślić wyjątkowość małżeństwa,

${ }^{9}$ O formach małżeństwa zob. Linderski 1984; Zabłocka 1988. Tradycyjnie za formułę inicjującą małżeństwo uważa się: Ubi tu Caius, ibi ego Caia. O jej znaczeniu i interpretacji zob. Treggiari 1991: 26-27. Zob. także: Stankiewicz 1996a oraz 1996b.

${ }^{10}$ Noniusz we wspomnianym lemmacie koncentruje się jednak na owej czynności kupowania czyniąc także wzmiankę o wiernej temu zwyczajowi Tetydzie, która pojawia się w Georgikach Wergiliusza (Georg. 1, 31): teque sibi generum Tethys emat omnibus undis, encyklopedysta nie rozwija jednak szerzej tego zagadnienia. 
które ma wyższą rangę niż to, co jest tylko zwyczajem ${ }^{11}$. Rzeczownik lex, oznacza zarówno przepis prawny, jak prawidło, regułę, przepis ${ }^{12}$.

To testimonium Warrona ukazuje jeszcze inny aspekt powinności żony. Ofiarowanie asów jest pierwszą czynnością wykonywaną przez pannę młodą, która od momentu deductio in domum i spełnieniu tego obowiązku staje się mater familias. Należy zaznaczyć, że powyższa praktyka wskazuje, iż kult Larów był ściśle związany z mater familias, która podczas wykonywania swoich codziennych obowiązków przebywała blisko paleniska, jako miejsca składania ofiar, i pełniła funkcję kapłanki. Ta powinność obejmuje również kult Larów Rozdroży, dlatego także tam umieszcza ona przyniesioną z domu rodzinnego monetę (trzecią).

Warto w tym miejscu zwrócić uwagę na pewną analogię powyższego testimonium Warrona ze starszym o ponad sto lat przekazem Katona zawartym w dziele $O$ rolnictwie (De agricultura 2 ):

Kiedy gospodarz zjawił się w posiadłości i oddał już cześć bóstwu domowemu, powinien, jeśli to możliwe, tego samego dnia obejść gospodarstwo ${ }^{13}$.

Pater familias, ubi ad villam venit, ubi larem familiarem salutavit, fundum eodem die, si potest, circumeat (...)

Wspomniany traktat Katona zawiera wiele rad i zaleceń kierowanych do właścicieli gospodarstw, którzy w czasach pisarza często nie mieszkali już na stałe na terenie swojej posiadłości. Celem tych pouczeń było umożliwienie Rzymianom osiągania zysków z działalności rolniczej, wynikające także z przekonania, że uprawa roli jest zajęciem godnym Rzymianina.

Właściciel, nazwany tu pater familias, pierwsze kroki po przyjeździe do swojej posiadłości kieruje do domowej kapliczki, w której umieszczony był wizerunek Lara rodzinnego w postaci malowidła bądź figurki. To domowe sanktuarium mieściło się w kuchni, w pobliżu ogniska, a codziennym kultem Lara podczas nieobecności pana domu zajmowała się gospodyni (vilica) ${ }^{14}$. Kult Lara uchodzi w oczach Katona za szczególnie ważny, ma zapewniać właścicielowi dostatek (copia) i zamożność poprzez obfite plony i wydajność gospodarstwa. Dziwić może brak wzmianki o innych domowych bóstwach, na przykład o Penatach bądź

${ }^{11}$ Wprowadzenie uporządkowanego prawodawstwa i unormowanie życia społecznego zazwyczaj przypisuje się królowi Numie Pompiliuszowi. Warron nie precyzuje, jak stary jest opisany przez niego zwyczaj. Jeśli potraktujemy przekaz uczonego dosłownie, to zwyczaj ten nie może sięgać dalej wstecz niż powstanie i rozpowszechnienie się monet. Możemy natomiast uznać go za starszy, jeśli założymy, że asy zastąpiły jakieś inne wręczane dawniej symboliczne dary.

12 Plezia 1959-1979: s.v. lex. Glare (1968: s.v. lex) podaje taką definicję: a law or rule established by divine authority or universally accepted by mankind, zaznacza, że może być to prawo lub zwyczaj uznany za pochodzący od bogów, zaakceptowany przez ludzi. Podobne znaczenie słowa lex podaje J. Korpanty (2001: s.v. lex): prawo, zasada, norma (boska, ogólnoludzka i in.).

${ }_{13}$ Przeł. I Mikołajczyk (Katon 2009: 58).

${ }^{14} \mathrm{O}$ znaczeniu religii w życiu Katona zob. Szczygieł 2011: 163-184. 
Weście, ale prawdopodobnie w przekonaniu pisarza nie pełniły one kluczowej roli w zapewnieniu mu dobrobytu.

Znamy wiele zabytków archeologicznych dokumentujących wygląd domowych kapliczek, głównie z Pompejów, ale pochodzą one z czasów późniejszych niż przekaz Warrona, a tym bardziej epoka, o której wspomina uczony. Są to często kunsztowne malowidła ścienne, niejednokrotnie wykonane w niszach o architekturze przypominającej świątynie. Umieszczano w nich figurki Larów, a także wielu innych bóstw, które były traktowane przez właścicieli jak dzieła sztuki, ponieważ przeważnie były wykonane z brązu przez utalentowanych rzemieślników ${ }^{15}$. Często lokalizacja tych domowych sanktuariów w miejscach odległych od miejsca przygotowywania bądź spożywania posiłków, dostępnych natomiast dla gości, takich jak na przykład atrium, wskazuje, że pełniły one rolę nie (tylko?) kultową, ale przede wszystkim informowały odwiedzających o guście i zamożności gospodarzy.

Pytanie jak wyglądało lararium (i czy w ogóle funkcjonowała taka nazwa, poświadczona znacznie później ${ }^{16}$ ) w wiejskiej posiadłości Katona, jak było urządzone w domu Warrona oraz jak autor De vita populi Romani wyobrażał sobie rzymski dom z dawnych czasów wraz z kuchnią - pozostaje bez odpowiedzi wobec braku dostatecznych źródeł archeologicznych i literackich. Bez wątpienia jednak takie miejsce istniało w dawnym domu rzymskim, być może była to niewielka półka w kuchni, na której umieszczano figurkę Lara i przedmioty związane z jego kultem. O istnieniu takich figurek, wówczas wykonanych najczęściej z drewna lub gliny, informuje nas tekst komedii Plauta Misa petna złota ${ }^{17}$ (Aulularia, 1-5), w której Lar jest jednym z bohaterów sztuki i wygłasza słynny prolog wprowadzający widza w akcję sztuki.

15 Clarke (2003: 75-78) oraz Krzyszowska (2003: 186). W Pompejach zlokalizowano dotąd około 300 larariów, z których większość datuje się na lata 62-79 n.e. O analizie materiału archeologicznego zachowanego w domach Pompejów oraz o proponowanym podziale larariów na właściwe (larari principali) i wtórne (larari secondari) zob. Giacobello 2008: 50-69. Tam także ewidencja i opis larariów pompejańskich. Zdjęcia larariów w: Boyce 1937 oraz Fröhlich 1991.

${ }^{16}$ Nie wiemy, kiedy zaczęto stosować nazwę lararium, która pojawia się w tekstach łacińskich dość późno i nie jest poświadczona w tekstach literackich epoki starożytnej. Prawdopodobnie po raz pierwszy spotykamy ją w tekście Historia Augusta, Vita Alexandri Severi, 29, 2; 31, 4-5. Urywki tego dzieła informują nas, że Aleksander Sewer miał prywatną kapliczkę nazywaną lararium, w której znajdowały się posążki Larów i Penatów, a także podobizny „,najważniejszych bogów” i „najlepszych wybranych”. W jego drugim lararium były podobizny Wergiliusza i Cycerona.

17 Plaut, Aulularia 1-5:

Ne quis miretur qui sim, paucis eloquar.

ego Lar sum familiaris ex hac familia

unde exeuntem me aspexistis. hanc domum

iam multos annos est cum possideo et colo

patri avoque iam huius qui nunc hic habet.

By nikt nie musiał łamać sobie głowy,

jak się nazywam, powiem wam w dwóch słowach:

ja jestem Larem. Tak, tak, Lar domowy 
Tekst Warrona kieruje nas do centralnego pomieszczenia w rzymskim domu, a mianowicie miejsca, w którym znajdowało się ognisko - palenisko - piec, fo$\mathrm{cus}^{18}$. Przygotowywano na nim posiłki, które spożywano w jego sąsiedztwie, po złożeniu codziennej ofiary bóstwom domowym, na przykład Geniuszowi pana domu, Penatom, czy oczywiście Larom. Panna młoda, która po raz pierwszy wchodzi do domu w nowej roli, składa Larowi swoją pierwszą ofiarę w postaci monety. Później, gdy będzie już mater familias, będzie samodzielnie przygotowywała przedmioty ofiarne: ciastka, soloną mąkę, wieńce z kwiatów itp., które w akcie ofiarnym będzie wrzucała do ogniska. Być może położona przy ognisku moneta posłuży do zakupu produktów ofiarnych.

W opisie zwyczaju przedstawionym przez Warrona zwraca uwagę określenie in pede, które mówi o miejscu przechowywania przez pannę młodą drugiej monety. Nietrudno sobie wyobrazić, że do takiego przeniesienia monety należało posłużyć się pełnym obuwiem, nieużyteczne wydają się do tego sandały ${ }^{19}$.

Warto w tym miejscu przyjrzeć się strojowi panny młodej, którego wygląd zależał od statusu materialnego jej rodziców i zmieniał się w różnych epokach. Składało się na niego kilka charakterystycznych części garderoby, które, między innymi poprzez swoją formę oraz kolory, pozwalały na identyfikację panny młodej wśród uczestników uroczystości weselnych oraz jednoznacznie wskazywały na okazję, przy której ów strój wkładano ${ }^{20}$.

W przeddzień ślubu narzeczona oplatała czerwoną siatką włosy, które następnego dnia układano w sześć loków (sex crines) przy pomocy specjalnego grzebienia nazywanego hasta caelibaris. Włosy dziewczyny okrywał ognistożółty welon, nazywany flammeum. Jej strój składał się z białej tuniki, przepasanej wełnianą wstęgą, czasem zawiązywaną na skomplikowany węzeł (nodus Herculeus). $\mathrm{Na}$ tunikę wkładano żółty płaszcz (palla), na stopy natomiast sandały. O takim obuwiu wspomina Katullus w Pieśni 61 (Carm. 61, w. 9-10), w której czytamy:

niveo gerens

luteum pede soccum.

tej tu rodziny. Już wieku połowa

minęła, odkąd strzegę i pilnuję

wpierw dziada, ojca, no a teraz tego,

co tutaj po nich w domu rezyduje.

Przeł. E. Skwara w: Plaut 2003.

${ }_{18}$ Rzeczownik focus ma następujące znaczenia: 1. palenisko domowe, kominek (zwt. $w$ atrium, gdzie czczony byt Lar Familiaris, używane do gotowania); palenisko w świątyni Westy 2. przen. (jako symbol zycia domowego) ognisko domowe, dom, rodzina, domownicy 3. palenisko < ołtarz > ofiarne/y; stos pogrzebowy (Korpanty 2001: s.v. focus); ognisko, palenisko, komin; przen. dom, ognisko domowe, rodzina, ołtarz (na którym płonął ogień poświęcony bogom) i in. (Plezia 1959-1979: s.v. focus).

${ }_{19}$ Trudno natomiast jednoznacznie zinterpretować przechowywanie monety in pede, prawdopodobnie ma to jakieś znaczenie symboliczne lub magiczne.

${ }^{20}$ O stroju oraz uczesaniu panny młodej w różnych epokach dziejów Rzymu: la Follette 2001: 54-64; Hersch 2010: 69-112. 
Wielu uczonych przyjmuje zatem, że obuwiem panny młodej były socci lutei, czyli złote, żółte lub ognistopomarańczowe sandały ${ }^{21}$, trudno to jednak pogodzić z możliwością ukrycia w nich monety.

Niewątpliwie ozdobą bogatej panny młodej była także biżuteria, podkreślająca jej pozycję społeczną.

O zwyczaju przynoszenia przez pannę młodą trzech asów do domu męża wspomina jedynie Warron. Jego świadectwo nie informuje nas jednak, czy w jego czasach był to zwyczaj ciągle kultywowany, ponieważ został określony jako stary (vetere lege) ani czy był szeroko rozpowszechniony. Jakie znaczenie miały wspomniane w testimonium Warrona asy?

As to oprócz srebrnej didrachmy, najdawniejsza moneta rzymska. Wywodzi się on z podłużnych brązowych płytek, aes signatum, które służyły do transakcji w epoce przedmonetarnej. Emitowana od początku III w. p.n.e. odlewana moneta nazywana aes grave miała wagę 12 uncji (czyli 324 g), która w ciągu kilkudziesięciu lat była kilkukrotnie redukowana aż do 1 uncji. Umieszczano na nich oznaczenia nominału (np. 1 as oznaczano symbolem $I$ ) oraz głowę Herkulesa (awers) i dziób okrętu (rewers). Prawdopodobnie od czasu drugiej wojny punickiej (dokładniej od lat 217-215 p.n.e.) jest to już moneta bita, a na jej awersie widnieje odtąd głowa Janusa.

O niezbyt dużej sile nabywczej asa świadczy wprowadzenie w ok. $211 \mathrm{r}$. p.n.e. srebrnego denara o wartości, jak sama nazwa wskazuje (deni - po dziesięć) dziesięciu asów. Emitowano także tak zwane wiktoriaty (od wizerunku bogini Wiktorii powożącej bigą, umieszczonego na rewersie) o wartości pół denara oraz bardzo popularne sesterce, stanowiące czwartą część denara (czyli 2,5 asa), które były najmniejszymi monetami srebrnymi czasów republiki. Spadek wartości asa nastąpił w trzeciej ćwierci II w. p.n.e., kiedy wartość denara podniesiono do 16 asów. Denary miały także duże znaczenie polityczne i propagandowe i często służyły urzędnikom (wybijającym monety z własnym nazwiskiem oraz z wizerunkami nawiązującymi do tradycji rodowej) do podkreśleniu zasług oraz znakomitości swojej rodziny. Emisja monety złotej na szerszą skalę następuje dopiero w latach czterdziestych I w. p.n.e., kiedy do obiegu wchodzi aureus o wartości 25 denarów. $\mathrm{W}$ roku 79 p.n.e. zaprzestano bicia monet z brązu (między innymi z powodu militarnego zapotrzebowania na ten surowiec), jednak wprowadzone pieniądze ciągle pozostawały w obiegu. Emitowanie asa przywrócono wkrótce na mocy reformy Augusta (zapoczątkowanej w 23 r. p.n.e.), wtedy jednak brąz zastąpiono stopem miedzi. Monetę wytwarzano do III w. n.e. ${ }^{22}$

W czasach Warrona, a zwłaszcza wtedy, gdy pisał on $O$ życiu narodu rzymskiego, czyli w latach czterdziestych I w. p.n.e., asy ciągle były w obiegu. Może

${ }^{21}$ Plezia 1959-1979: s.v. luteus, -a, -um - zielono-żółty, blady; różowy, jasnoczerwony. O "złotych" sandałach: Treggiari 1991: 163.

${ }^{22}$ Wyczerpująco zagadnienia monetarne Rzymu przedstawia Awianowicz 2010: 7-17. Zob. także: Depeyrot 2006: 212. 
także świadomość odchodzenia w przeszłość tej monety skłoniła Reatyńczyka do utrwalenia na piśmie owego ślubnego zwyczaju.

Trzeci as jest przynoszony przez pannę młodą w specjalnej torebce, nazwanej sacciperio $^{23}$. Miała ona prawdopodobnie charakterystyczny kolor lub kształt wskazujący na wyjątkowe okoliczności jej użycia, czyli przyniesienia asa z okazji zamążpójścia.

Lakoniczność notatki Warrona jest powodem pewnych wątpliwości dotyczących tej monety, którą panna młoda składa w ofierze Larom na rozdrożu (compitum). Dodatkowym problemem jest także uszkodzenie tekstu: solere $\uparrow$ resenare, które uniemożliwia dokładne jego zrozumienie. Domyślamy się, że chodzi o sposób „podarowania” monety Larom Rozdroży, niestety, pozostaje on dla współczesnego badacza niejasny. Rodzi się jednak pytanie, na którym rozdrożu składała ona ofiarę oraz druga wątpliwość, czy ta wizyta na compitum miała miejsce w dniu ślubu, czy później.

Compitum, czyli miejsce, gdzie zbiegają się drogi, kojarzone jest przede wszystkim z kultem Larów Rozdroży, który w świetle testimoniów łączy się ściśle z uroczystościami agrarnymi i jest jednym z rolniczych świąt obchodzonych na przełomie roku. Podczas Kompitaliów, pod koniec grudnia, bądź w pierwszych dniach stycznia (było to święto ruchome, z kategorii feriae conceptivae, którego datę corocznie wyznaczał pretor) na rozdrożu (compitum) gromadzili się wszyscy mieszkańcy i gospodarze, w tym także niewolnicy, którzy przy znajdujących się tam kapliczkach składali ofiary Larom w intencji opieki nad uprawami, dostatku i pomyślności wszystkich uczestników ${ }^{24}$. Takie compita znajdowały się na terenach wiejskich oraz w Rzymie, który podzielony był na niewielkie jednostki nazywane vici (l. poj. vicus) ${ }^{25}$. Każdy z tych vici miał swój ołtarz (zachowały się takie ołtarze z czasów Augusta ${ }^{26}$ ), przy którym z okazji Kompitaliów gromadzili się mieszkańcy danego vicus. Było to także miejsce, jak przekazują nam starożytni, które odwiedzano podczas ważnych wydarzeń rodzinnych lub osobistych, na przykład (poza omawianym zawarciem małżeństwa) z okazji osiągnięcia dojrzałości przez chłopca i przywdziania przez niego togi męskiej (toga virilis) czy też ofiarowania Larom bullii ${ }^{27}$.

${ }^{23} \mathrm{~W}$ tekście Warrona występuje rzeczownik sacciperio, onis (m), natomiast słowniki, w tym wskazane poniżej, podają tylko jeden cytat poświadczający występowanie tego wyrazu i to w innej formie: sacciperium, (Plautus, Rudens 548: plenum argenti fuit in sacciperio), którego użycie w literaturze jest bardzo rzadkie. Plezia 1959-1979: s.v. sacciperium - (zł. z saccus i pera) torba, sakwa.

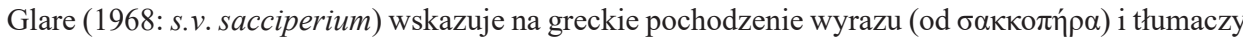
go mianem wallet - portfel.

${ }^{24}$ Szerzej o Kompitaliach: Kaczor 2012: 225-229, 248-250; Kaczor 2015: 53-64; Beard et al. 2017: 216-219.

${ }^{25}$ Rzym był podzielony na jednostki administracyjne, większe - regiones (dzielnice miasta) oraz mniejsze - vici (szeregi domów, dzielnice).

${ }^{26}$ Ołtarze z czasów Augusta przedstawia: Lott 2004: 141-149.

${ }^{27}$ Bulla była to kapsuła skórzana bądź metalowa z umieszczonym wewnątrz amuletem, którą dzieci nosiły na szyi, jako ochroną przez złymi mocami. Zob. Plaut, Rud. 1171: bulla aurea est, 
Panna młoda składała zatem ofiarę Larom Rozdroży przy ołtarzu należącym do vicus, na którego terenie znajdował się dom jej męża. Oznaczało to wejście do nowej społeczności, w której od tej pory będzie obchodziła Kompitalia. Oddawała się zatem w opiekę Larom strzegącym tego terenu i trzymającym pieczę nad bezpieczeństwem oraz dostatkiem jego mieszkańców.

Uszkodzenie tekstu nie pozwala nam wnioskować, w jaki sposób ofiarowano owego asa. Czy przy ołtarzu znajdowała się skarbonka, z której później finansowano ofiarę składaną z okazji Kompitaliów? Niestety, źródła antyczne, bardzo skąpe i wyrywkowe, nie potwierdzają tego przypuszczenia. Z pewnością jednak przejście panny młodej do ołtarza na compitum było wydarzeniem publicznym, widocznym dla innych mieszkańców i znakiem zmiany, która zaszła w gronie lokalnej społeczności. Poświadczało także i unaoczniało nowy status kobiety jako mater familias.

Zamiłowanie Warrona do tradycji i chęć jej utrwalenia zarówno na piśmie, jak i zachowania w życiu codziennym świadczy o tym, że w opinii antykwarysty opisany przez niego zwyczaj jest ważny i zasługuje na kontynuowanie.

Trzeba zaznaczyć, że rytuał ofiarowania asów obrazuje istnienie uporządkowanego świata widzialnego - relacja między mężem i żoną, oraz niewidzialnego - relacje z Larami Rodzinnymi i Larami Rozdroży. Akcentowana często zależność żony od męża, a nawet jej podległość (przejawiająca się między innymi w prawie życia i śmierci wobec wszystkich członków rodziny) nabiera w świetle tego testimonium innego wymiaru. Jeśli bowiem złożenie asów Larom przez pannę młodą służy oddaniu się jej w opiekę domowym i lokalnym bóstwom, to można domniemywać, że przekazanie monety mężowi także łączy się z faktem przyjęcia przez męża obowiązku otoczenia żony troską i ochroną. Żona natomiast, zajmująca się na co dzień sprawami domowymi i sprawująca codziennie kulty bóstw domowych, dbała o dobrostan oraz pomyślność rodziny ${ }^{28}$. Stanowiło to podstawę dobrego i szczęśliwego jej funkcjonowania. Być może właśnie dlatego Warron, a kilka wieków później leksykograf Noniusz (IV w. n.e.) przypominają o zwyczaju składania w ofierze asów.

\section{Bibliografia}

Albrecht von, M. (1997). A History of Roman Literature. From Livius Andronicus to Boethius, vol. I. Leiden-New York-Köln: E. Brill.

Awianowicz, B.B. (2010). Monety Republiki Rzymskiej. Kompendium. Toruń: Wydawnictwo Literat.

quam dedit mi natali die. O zwyczaju składania bulli: Persius, Saturae 5, 31. Szerzej, także o ofiarowaniu Larom lalek przez dziewczęta, w komentarzu do utworów Horacego: Pseudo-Acron, Horatii Sat. 1, 5, 65-66: Solebant pueri, postquam pueritiam excedebant, dis Laribus bullas suas consecrare, similiter et puellae pupas.

${ }^{28} \mathrm{O}$ kultach domowych, Westy, Larów, Penatów, Geniusza ojca rodziny i innych zob. Schultz 2006: 121-138. 
Beard, M. et al (2017). Religie Rzymu. Historia. Tłumaczenie zbiorowe pod red. M.J. Baranowskiego i L. Olszewskiego. Oświęcim: Napoleon V. (Oryginał: Beard M. et al [1998]. Religions of Rome. History. Cambridge: Cambridge University Press).

Benincasa, Z. (2013). „Deductio in domum mariti a zawarcie iustum matrimonium”. Zeszyty Prawnicze 13 (2). 7-25.

Boyce, G. (1937). Corpus of the Lararia of Pompeii. Memoirs of the American Academy in Rome 14. Rome: University of Michigan Press.

Clarke, J.R. (2003). Art in the Lives of Ordinary Romans. Visual Representation and Non-Elite Viewers in Italy 100 B.C.-A.D. 315. Berkeley-Los Angeles-London: University of California Press.

Cornell, T., Bispham, E. (red.) (2013). The Fragments of the Roman Historians, t. 1. Oxford: Oxford University Press.

Depeyrot, G. (2006). La Monnaie romaine. 211 av. J.-C.-476 apr. J.-C. Paris: Éditions Errance.

Flower, H.J. (2017). The Dancing Lares and the Serpent in the Garden. Religion at the Roman Street Corner. Princeton University Press.

Follette la, L. (2001). The Costume of the Roman Bride. W: Sebesta, J.L., Bonfante, L (red.). The World of Roman Costume. Madison: University of Wisconsin Press.

Fröhlich, T. (1991). Lararien- und Fassadenbilder in den Vesuvstädten, Untersuchungen zur ,, volkstümlichen" pomejanischen Malerei. Mainz: Philipp von Zabern.

Giacobello, F. (2008). Larari pompeiani. Iconografia e culto dei Lari in ambito domestico. Milano: Università degli studi di Milano.

Glare, P.G.W. (1968). Oxford Latin Dictionary. Oxford: Clarendon Press.

Hersch, K.K. (2010). The Roman wedding. Ritual and Meaning in Antiquity. Cambridge: Cambridge University Press.

Kaczor, I. (2012). Deus. Ritus. Cultus. Studium na temat charakteru religii starożytnych Rzymian. Łódź: Wydawnictwo Uniwersytetu Łódzkiego.

Kaczor, I. (2015) „Ofiary z ludzi w obrzędowości rzymskiej - Mamuralia, Sacra Argeorum, Saturnalia, Kompitalia". Collectanea Philologica 18. 53-64.

Katon (2009). Marek Porcjusz Katon. O gospodarstwie rolnym, z jęz. łac. przełożył, wstępem i komentarzem opatrzył: I. Mikołajczyk. Toruń: Wydawnictwo Naukowe Uniwersytetu Mikołaja Kopernika.

Korpanty, J. (red.) (2001). Stownik tacińsko-polski, t. I-II. Warszawa: Wydawnictwo Szkolne PWN.

Krzyszowska, A. (2003). Les cultes privés a Pompéi. Wrocław: Wydawnictwo Uniwersytetu Wrocławskiego.

Kumaniecki, K. (1977). Literatura rzymska. Okres cyceroński. Warszawa: Państwowe Wydawnictwo Naukowe.

Lind, G. (2008). Common Law Marriage. A Legal Institution for Cohabitations. Oxford: Oxford University Press.

Linderski, J. (1984). „Usu, farre, coemptione. Bemerkungen zur Überlieferung eines Rechtsatzes“. Zeitschrift Der Savigny-Stiftung Für Rechtsgeschichte. Romanistische Abteilung 101 (1). 301-311.

Lott, J.B. (2004). The Neighborhoods of Augustan Rome. Cambridge: Cambridge University Press.

Marshall, F.H. (19213). A Companion to Latin Studies. Red. by John Edwyn Sandys. Cambridge: Cambridge University Press.

Modestinus (2014). Digesta Iustiniani, Digesta Justyniańskie, IV, ks. 20-27. Tekst, przekład pod red. T. Palmirskiego, praca zespołowa (K. Hilman, M. Hładyszewska, T. Palmirski, J. Reszczyński, H. Wolanin), przy współpracy P. Niczyporuka (ks. 25, 26). Kraków: Poligrafia Salezjańska.

Mommsen, T. (red.) (1872). Corpus iuris civilis. Vol. 1. Iustiniani digesta. Berolini: apud Weidmannos.

Myśliwiec, H. (1990). Varro, Marcus Terentius. W: Świdarkówna, A. (red.). Stownik pisarzy antycznych. Warszawa: Wiedza Powszechna. 470-472.

Nonius, M. (1903). De compendiosa doctrina libri XX. W: Lindsay W.M., t. I-III. Lipsiae: B.G. Teubner. 
Plaut (2003). Komedie, tom II: Osły, Misa petna złota. Przełożyła, wstępem i przypisami opatrzyła E. Skwara. Warszawa: Wydawnictwo Prószyński i S-ka.

Plezia, M. (red.) (1959-1979). Stownik tacińsko-polski, t. I-V. Warszawa: Państwowe Wydawnictwo Naukowe.

Rozwadowski, W. (1987). „Nowe badania nad istotą małżeństwa rzymskiego”. Meander 42 (4-5). $237-247$.

Schultz, C.E. (2006). Women religious activity in the Roman Republic. Chapel Hill: University of North Carolina Press.

Stankiewicz, L. (1996a). „Małżeństwo w starożytnym Rzymie. Gdzie ty, Gajusz, tam ja, Gaja”, cz. 1, Kurier Plus 96/432, szp. 17, New York.

Stankiewicz, L. (1996b). „Rozwód w starożytnym Rzymie. Gdzie ty, Gajusz, tam ja, Gaja”, cz. 2, Kurier Plus 97/432, szp. 12, New York.

Szczygieł, S. (2011). Marek Porcjusz Katon - rzymski tradycjonalista czy polityk realista. Warszawa: Wydawnictwo DiG.

Treggiari, S. (1991). Roman Marriage. Iusti Coniuges from the Time of Cicero to the Time of Ulpian. Oxford: Oxford University Press.

Varro, M.T. (1939). M. Terenti Varronis De vita populi Romani. Fonti, Esegesi, Edizione Critica dei Frammenti. Red. Benedetto Riposati. Milan: Pubblicazione dell' Università Cattolica del Sacro Cuore.

Varro, M.T. (2004). M. Terenti Varronis Fragmenta omnia quae extant. Pars II. De vita populi Romani libri IV. Red. Marcello Salvadore. Hildesheim-Zurich-New York: Georg Olms.

Wołodkiewicz, W., Zabłocka, M. (1996). Prawo rzymskie. Instytucje. Warszawa: C.H. Beck.

Zabłocka, M. (1988). „Confarreatio w ustawodawstwie pierwszych cesarzy rzymskich”. Prawo Kanoniczne: kwartalnik prawno-historyczny 31 (1-2). 237-246.

dr Barbara Hartleb-Kropidło (Uniwersytet Wrocławski) - a lecturer in Institute of Classical, Mediterranean and Oriental Studies. Her main areas of interest are archaic Roman poetry, especially drama, ancient religions and cults of Italy and Rome. Her current research is concerned with the archaic Roman cult of Lares. e-mail: barbara.hartleb-kropidlo@uwr.edu.pl 